coloured beam is the same as that of a white beam of the same intensity. This conclusion was quite definite for the winter fogs in Surrey, near the National Physical Laboratory. There is a possibility that the conclusions may not hold good for other kinds of fog.

\section{Earth-Sounds in the East Indies}

Capt. P. Jansen, St. Helens Court, London, E.C.3, has sent us an interesting account of sounds heard by him near the mouths of rivers in the Dutch East Indies. Except in their higher pitch, they seem to resemble the barisal guns of the Ganges delta and the brontides of certain districts in Italy. On the roads of Sourabaya in Java, he says, two or three noises, as of foghorns of different notes, were heard at irregular intervals of a few seconds, each lasting for one or two seconds. In the hold of an empty ship, the noise was deafening. After continuing for one or two hours, the noises ceased as suddenly as they began. Capt. Jansen has heard the same noises, but less frequently, at the mouth of the Palembang River in Sumatra. At the mouths of some of the rivers of the Malay Peninsula, other noises were heard, like that of plucking the strings of a musical instrument, all on the same note and at irregular intervals. Although barisal guns and brontides have for a long time been carefully studied, their origin is still obscure. They are heard frequently in seismic districts and also in countries free from earthquakes. Possibly they have more than one origin, but their frequent occurrence near the mouths of great rivers seems to connect them with the settling of the delta or of the underlying crust.

\section{International Scientific Management}

IT is now ten years since the first international conference was held in Prague at which papers dealing with various aspects of scientific management were read. That the intervening period has not been barren of results is the opinion of numerous European and American engineers and men of science who have contributed to the volume, "After Ten Years" ("Po desiti letech"), which has just been issued by the Masaryk Academy of Work under the editorship of Dr. S. Spaček, the Czechoslovak engineer who presided at the inaugural meeting in 1924. The next conference is to be held in London during July 1935, and will be under the auspices of the Federation of British Industries. In view of the many remarkable changes in outlook concerning industrial management, this conference should prove of considerable interest. One authority refers to the fact that scientific management was originally concerned. exclusively with output by employees, whereas to-day attention is being focused upon wasteful administrative methods. It is considered that there is scope for much improvement in this direction.

\section{Princeton Institute for Advanced Study}

AN interesting account of the origin of this institute is given in Scripta Mathematica (1, No. 2) and reproduced in the Indian journal, the Mathematics Student (2, No. 2). Mr. Bamburger and Mrs.
Felix Fuld were much impressed by Dr. Flexner's well-known book, "Universities : American, English, German", and they asked the author what centre of learning he would organise if adequate funds were placed at his disposal. Dr. Flexner, after consultation with scholars throughout the world, replied that he regarded mathematics as the most fundamental of all disciplines, and suggested setting up a School of Mathematics. Mr. Bamburger and Mrs. Fuld accepted Dr. Flexner's ideas and gave five million dollars to have them put into effect. Prof. Einstein is director of the institute, which includes also Profs. Veblen and Weyl. Scholarships and fellowships are available for suitably qualified students. These are under the supervision of the professors, but there are no hardand-fast rules, and each professor is at liberty to adopt whatever methods, formal or informal, he considers best calculated to promote research. This is an important point, since many consider that research institutes have a fatal tendency to become over-organised, to the detriment of original thought.

\section{Positions in the Tristan d'Acunha Group}

IT has recently been discovered that certain positions in the Tristan d'Acunha group are incorrectly quoted in vol. 1, Part 1 of the "Report of Scientific Results of the Exploring Voyage of H.M.S. Challenger 1873-76"'. The principal effect of these errors is to place Inaccessible and Nightingale Island in incorrect positions relative to Tristan Island. A full account of the origin of these errors, with a description of the sequence of events which led to their discovery, has been published in the Empire Surveyors Review (vol. 2, No. 13, July 1934).

\section{Exhibition of Kinematography}

The Royal Photographic Society, at its house at 35 Russell Square, is holding an exhibition of kinematography until November 30. The exhibition will be open from 10 a.m. to 6 p.m. daily, and a number of public lectures has been arranged. Admission is free. Particulars may be obtained from the Secretary of the Society. The opening lecture was given on November 6 by Mr. F. F. Renwick who described the Dufay colour process. As already mentioned in NAture $(133,678 ; 1934)$, this process was to be made available to users of $16 \mathrm{~mm}$. kine film during the summer of this year. When the film was issued it was found to be extremely successful. In his lecture, Mr. Renwick stated that a very large amount of research work had been carried out relating to the application of the process to the full-size kine film. In making copies, much progress had been made, and he was able to exhibit samples made both by projection and contact printing. This accomplishment has already been followed by prominent film-producing companies, and soon Dufay colour films will, no doubt, be included in screen programmes.

\section{A Photographic Centenary}

THE year 1834 is famous for the production of the earliest recorded photograph on paper. This was the work of Henry Fox Talbot, who used paper 